\title{
Peningkatan Hasil Belajar Peserta Didik Melalui Pendekatan PMRI materi Bangun Ruang Di Kelas V SDN No. 35 Inpres Panggalo, Kabupaten Majene
}

\author{
Megawati Sitompul $^{1 *}$, Elin ${ }^{1}$, Hijriah $^{1}$, Putri $^{1}$ \\ 1. Universitas Terbuka \\ *e-mail: megawati.sitompul1994@gmail.com,ellinazzahra@gmail.com
}

\begin{abstract}
Abstrak
Penelitian ini bertujuan untuk mengetahui peningkatan hasil belajar matematika pada materi bangun ruang melalui pendekatan Pendidikan Matematika Realistik Indonesia (PMRI) pada peserta didik kelas V SDN No.35 Inpres Panggalo, Kecamatan Banggae, Kabupaten Majene. Jenis penelitian ini adalah Penelitian Tindakan Kelas (Classroom Action Research) yang terdiri dari empat tahap, yaitu tahap perencanaan, pelaksanaan, observasi dan refleksi. Subjek penelitian ini adalah peserta didik kelas V SDN No.35 Inpres Panggalo tahun pelajaran 2018-2019 yang berjumlah 20 peserta didik, terdiri dari 13 peserta didik laki-laki dan 7 peserta didik perempuan. Penelitian ini dilaksanakan dalam dua siklus. Teknik yang digunakan dalam pengumpulan data adalah teknik observasi dan tes tertulis. Hasil penelitian menunjukkan bahwa penerapan pendekatan Pendidikan Matematika Realistik Indonesia (PMRI) dapat meningkatkan motivasi dan hasil belajar peserta didik. Peningkatan hasil belajar dapat dilihat dari nilai yang diperoleh. Pada siklus I rata-rata nilai yang diperoleh adalah 69,25 meningkat pada siklus II menjadi 78. Jumlah peserta didik yang mencapai ketuntasan pada siklus I sebanyak 12 peserta didik atau sebesar $67 \%$ dan pada siklus II meningkat menjadi 17 peserta didik atau sebesar $88 \%$. Dengan melihat persentase dari siklus I ke siklus II, menunjukkan adanya peningkatan hasil belajar peserta didik sebesar $21 \%$.
\end{abstract}

Kata kunci: Hasil Belajar, Pendekatan PMRI, Peningkatan.

\section{PENDAHULUAN}

Perkembangan zaman di era modernisasi, ilmu pengetahuan dan teknologi mengalami kemajuan yang sangat pesat. Hal tersebut merupakan faktor dominan yang telah membentuk eksistensi kehidupan umat manusia. Temuan-temuan baru hasil riset secara langsung atau tidak merupakan kenyataan yang tidak dapat dipungkiri, dapat membawa perubahan dan peradaban pada hidup manusia. Penggunaan alat dan sarana kebutuhan hidup yang modern telah memungkinkan pola pikir dan sikap, serta tindakan manusia melalui nilai-nilai baru sesuai dengan intensitas pengaruh teknologi tersebut terhadap tatanan kehidupan sosial budaya.

Berkat kemajuannya, pendidikan ditantang mampu mempersiapkan sumber daya manusia yang berkualitas dan kaya dengan ilmu pengetahuan. Untuk menghadapi persaingan global, manusia haruslah mempunyai pendidikan yang mencukupi agar menjadi bekalnya untuk memperbaiki diri di masa depan. Karena dalam pendidikan mengandung transfortasi ,nilai-nilai serta keterampilan yang diperlukan. Undang-undang No. 20 tahun 2003 tentang Sistem Pendidikan Nasional menyatakan bahwa Pendidikan adalah usaha sadar dan terencana untuk mewujudkan suasana belajar dan proses pembelajaran, agar peserta didik secara aktif mengembangkan potensi dirinya untuk memiliki kekuatan spritual keagamaan, pengendalian diri, kepribadian, kecerdasan, akhlak mulia, serta keterampilan yang diperlukan bagi dirinya, 
masyarakat, bangsa dan negara. Untuk mewujudkan pendidikan yang demikian, tidak terlepas dari beberapa komponen di dalamnya. Antara lain tujuan, pendidik, peserta didik, alat dan lingkungan. Apabila salah satu komponen tidak ada, maka pendidikan tidak berjalan dengan baik, bahkan tujuan pendidikan tidak akan tercapai.

Di sekolah, guru sebagai figur yang menempati posisi penting memegang peranan dalam pendidikan. Guru sangat berpengaruh terhadap terciptanya generasi penerus di masa depan yang kaya dengan penguasaan terhadap ilmu pengetahuan dan teknologi. Dikarenakan, guru berhadapan langsung dengan peserta didik untuk melakukan transfer ilmu pengetahuan dan teknologi sekaligus mendidik dengan nilai-nilai positif melalui bimbingan dan keteladanan.

Guru memiliki misi dan tugas yang berat, namun mulia dalam menghantarkan anak-anak bangsa dalam meraih cita-cita. Sebagai guru, perlu mengetahui bahwasanya kemampuan peserta didik yang beragam. Di dalam kegiatan pembelajaran, guru akan dihadapkan dengan sejumlah karakteristik peserta didik yang berbeda-beda dan perlu disadari bahwa sebenarnya di antara peserta didik, terdapat anak yang memerlukan perhatian atau pelayanan khusus seperti anak berkesulitan belajar.

Kesulitan belajar merupakan fenomena baru yang masih kurang dipahami oleh para pengelola pendidikan pada umumnya. Istilah ini sering dikaitkan dengan anak yang lambat belajar, prestasi yang lebih rendah maupun kesulitan belajar khusus. Bahkan ada sebagian ahli yang berpendapat bahwa kesulitan belajar merupakan bagian dari pendidikan luar biasa (Yusuf, 1997).

Kesulitan belajar adalah suatu keadaan yang menyebabkan peserta didik tidak dapat belajar sebagaimana mestinya. Kesulitan belajar yang dihadapi disebabkan oleh adanya kesukaran dalam menerima atau menyerap pelajaran di sekolah (Muhammad Suardi, 2015: 100). Prestasi belajar peserta didik yang mengalami kesulitan belajar lebih rendah bila dibandingkan dengan prestasi belajar temannya. Kesulitan belajar itu menunjukkan adanya suatu jarak antara prestasi akademik yang diharapkan dengan prestasi akademik yang dicapai oleh peserta didik. Oleh karenanya, peserta didik yang mengalami kesulitan belajar segera diberi bantuan dalam belajar (Blasic dan Jones dalam Sugihartono, 2007).

Kenyataan menunjukkan bahwa ternyata masih banyak sekali masalah yang dihadapi guru dan peserta didik dalam pembelajaran. Salah satu di antaranya adalah kesulitan dalam belajar matematika. Matematika merupakan ilmu yang mendasari daya pikir manusia untuk kemajuan teknologi modern. Matematika membekali peserta didik dengan kemampuan berfikir logis, analitis, sistematis, kritis, kreatif serta kemampuan bekerja sama. Dengan demikian, matematika perlu dikuasai untuk menghadapi perkembangan ilmu pengetahuan dan teknologi (Hawa: 2007).

Peran guru harus mampu membantu peserta didik untuk mengatasi kesulitan belajar. Guru perlu mengupayakan adanya situasi, kondisi, strategi, materi, maupun teknik bantuan belajar matematika yang menyenangkan. Pembelajaran yang menyenangkan menuntut adanya kebebasan pembelajaran, sehingga peserta didik dapat mengungkapkan makna sebagai hasil dan interprestasinya terhadap segala sesuatu yang ada di dunia nyata. Sedangkan pembelajaran bermakna merupakan suatu proses yang dikaitkannya informasi baru pada konsep-konsep relavan yang terdapat dalam struktur kognitif seseorang (Trianto, 2007:25). 
Proses pembelajaran yang sesuai dengan tujuan pendidikan matematika akan menjadikan pembelajaran lebih bermakna dan menyenangkan. Untuk mendukung tercapainya tujuan tersebut, maka diperlukan pengembangan materi pelajaran yang difokuskan pada aplikasi dalam kehidupan sehari-hari dan disesuaikan dengan tingkat kognitif peserta didik. Selanjutnya, apabila anak belajar matematika terpisah dari pengalaman mereka sehari-hari, maka anak akan cepat lupa dan tidak dapat mengaplikasikan matematika (Van de HenvelPanhuizen dalam I Gusti Putu Suharta, 2005: 579).

Dalam pembelajaran matematika di Sekolah Dasar, untuk mencapai tujuan belajar bukanlah perkara yang mudah, banyak sekali kendala yang ditemui. Banyak peserta didik yang memandang matematika sebagai salah satu mata pelajaran yang sulit dipahami dan dimengerti. Seperti halnya pembelajaran matematika di SDN No. 35 Inpres Panggalo, Kecamatan Banggae, Kabupaten Majene. Dari tinjauan observasi dan wawancara yang peneliti telah lakukan di kelas $\mathrm{V}$, menunjukkan bahwa pada saat pembelajaran berlangsung terdapat sebagian peserta didik yang mengalami kesulitan belajar, dikarenakan oleh guru yang kurang variatif dalam memanfaatkan strategi ataupun teknik bantuan belajar. Menyebabkan hasil belajar peserta didik rendah dan tidak mencapai nilai Kriteria Ketuntasan Minimal (KKM) yaitu 65.

Berdasarkan latar belakang permasalahan yang telah dikemukakan, maka perlu dilakukan penelitian yang bertujuan untuk mengetahui peningkatan hasil belajar matematika pada materi bangun ruang melalui pendekatan Pendidikan Matematika Realistik Indonesia (PMRI) pada peserta didik kelas V SDN No.35 Inpres Panggalo, Kecamatan Banggae, Kabupaten Majene.

\section{Metode}

Penelitian ini dilakukan dengan menggunakan metode Penelitian Tindakan Kelas (PTK) atau Classrooom Action Research (CAR), merupakan salah satu bentuk penelitian yang sejak lama berkembang di negara- negara maju seperti Inggris, Australia dan Amerika, dimana melalui penelitian ini mampu menawarkan cara dan prosedur baru untuk memperbaiki dan meningkatkan profesionalisme dalam proses belajar mengajar di kelas dengan melihat indikator keberhasilan proses pembelajaran.

Dalam penelitian yang dilakukan, peneliti menggunakan dua siklus. Pembagian siklus didasarkan pada materi yang akan dilaksanakan, dimana setiap siklus terdiri dari empat tahapan yaitu:

\section{Perencanaan (Planning)}

Tahap perencanaan merupakan tahap awal yang merupakan kegiatan untuk menentukan langkah-langkah yang akan dilakukan oleh peneliti untuk memecahkan masalah yang akan dihadapi.

Dalam penelitian yang dilakukan, dikatagorikan sebagai tahap perencanaan adalah sebagai berikut:

a. Menelaah materi pembelajaran dan menelaah indikator bersama tim kolaborasi;

b. Menyusun RPP sesuai dengan indikator yang telah ditetapkan dan skenario pembelajaran matematika pendekatan Pendidikan Matematika Realistik (PMRI);

c. Menyiapkan sumber dan alat peraga yang dibutuhkan dalam pembelajaran;

d. Menyiapkan alat evaluasi berupa tes tertulis dan lembar kerja peserta didik; 
e. Menyiapkan lembar observasi untuk mengamati kinerja guru, aktivitas peserta didik dan iklim belajar dalam pembelajaran.

2. Pelaksanaan Tindakan (Acting)

Tahap pelaksanaan adalah implementasi dari semua rencana yang telah dibuat dan berlangsung di dalam kelas serta terealisasi dari segala teori pendidikan dan teknik mengajar yang telah disipkan sebelumnya. Yaitu melaksanakan tindakan kelas dengan menerapkan pendekatan PMRI.

\section{Pengamatan (Observation)}

Observasi adalah suatu upaya pengumpulan data berkenaan dengan pelaksanaan tindakan kelas. Pada tahap observasi, peneliti dibantu guru kolaborator mengobservasi faktor-faktor rendahnya hasil belajar peserta didik selama proses pembelajaran dengan menggunakan lembar observasi. Dengan lembar observasi guru, observer juga mengamati dan memberikan penilaian terhadap peneliti dalam menerapkan pendekatan PMRI selama proses pembelajaran.

\section{Refleksi (Reflecting)}

Refleksi adalah mengingat, merenungkan, mencermati, dan menganalisis kembali suatu kegiatan atau tindakan yang telah dilakukan sebagaimana yang telah dicatat dalam observasi. Setelah pelaksanaan tindakan selesai dilaksanakan, guru pelaksana, peneliti dan subjek peneliti mendiskusikan implementasi rancangan tindakan. Tahapan refleksi dilakukan untuk menemukan hal-hal yang sudah sesuai dengan rancangan maupun hal-hal yang perlu diperbaiki.

Pada tahap refleksi, hasil yang diperoleh dari pengamatan dikumpulkan dan dianalisis bersama peneliti dan observer, sehingga dapat diketahui apakah kegiatan yang dilaksanakan sesuai dengan tujuan yang diharapkan atau masih perlu adanya perbaikan yang akan diterapkan pada penelitian berikutnya.

Adapun bagan dari desain penelitian tersebut sebagai berikut

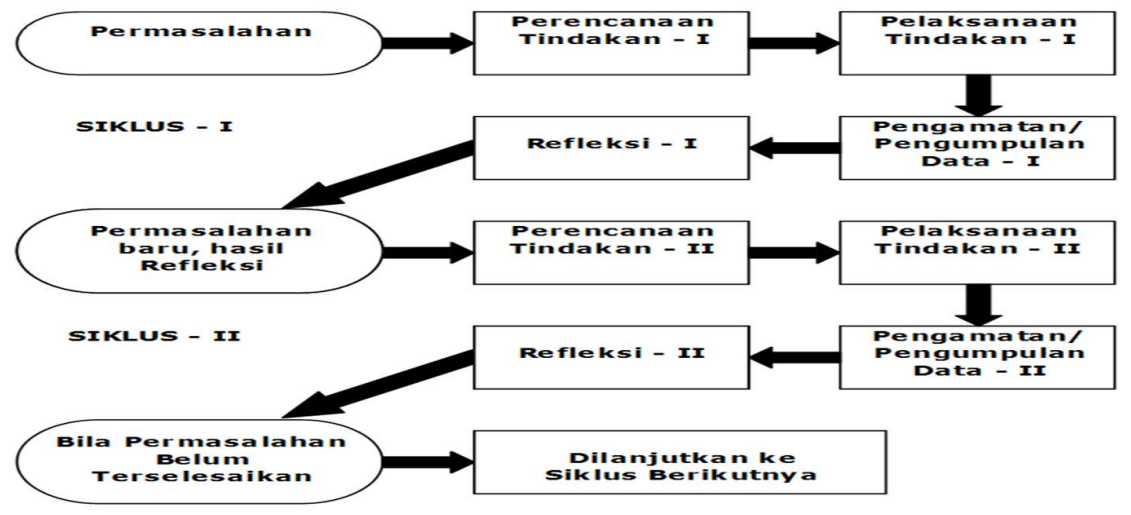

Gambar 2.1 Diagram Desain Penelitian

Penelitian Tindakan Kelas yang dilakukan, direncanakan dalam 2 siklus. Hal tersebut dimaksudkan untuk melihat bagaimana keberhasilan peserta didik di setiap siklus pada setiap tindakan. Apabila penelitian pada siklus I terdapat kekurangan maka penelitian pada siklus II lebih diarahkan pada perbaikan. 
Analisis data adalah kegiatan mencermati, menguraikan, mengaitkan, setiap informasi yang terkait dengan kondisi awal, proses belajar, dan hasil pembelajaran untuk memperoleh kesimpulan tentang keberhasilan tindakan perbaikan pembelajaran (Muhadi, 2011: 140).

Data dalam penelitian ini terdiri dari dua jenis, antara lain:

1. Data kualitatif, adalah data yang berupa kalimat atau pernyataan bukan berupa angka yang menggambarkan hasil pengamatan observer terhadap aktivitas peserta didik selama proses berlangsungnya pembelajaran.

2. Data kuantitatif, merupakan data yang berupa angka-angka dan bersifat objektif berupa nilai hasil belajar peserta didik yang dianalisis dengan cara mencari nilai rata-rata atau persentase keberhasilan belajar.

Dalam menganalisis tingkat keberhasilan peserta didik setelah kegiatan belajar mengajar pada setiap siklus dilakukan, selanjutnya diakhiri dengan memberikan evaluasi. Dengan mengacu pada teknik penguasaan peserta didik terhadap materi belajar, maka digunakan kategori tingkat penguasaan sumber kemendikbud, yaitu.

\begin{tabular}{cc} 
Rentang Nilai & Kategori \\
\hline $0 \%-64 \%$ & Kurang \\
$65 \%-75 \%$ & Cukup \\
$76 \%-87 \%$ & Baik \\
$88 \%-100 \%$ & Sangat Baik \\
\hline
\end{tabular}

Tabel 2.1 Rentang Nilai Peserta didik $(\mathrm{KKM}=65)$

Untuk mengetahui adanya peningkatan peserta didik, dilakukan dengan menghitung persentase nilai rata-rata kelas hasil evaluasi dengan rumus sebagai berikut :

Keterangan :

$$
\mathrm{M}=\frac{\sum \mathrm{x}}{N} \times 100 \%
$$

$\mathrm{M}=$ Rata-rata

$\sum \mathrm{x}=$ Jumlah seluruh skor

$\mathrm{N}=$ Jumlah peserta didik

Sedangkan untuk menghitung persentase ketuntasan belajar peserta didik digunakan rumus sebagai berikut :

Keterangan :

$$
\mathrm{P}=\frac{f}{N} \times 100 \%
$$

$\mathrm{P}=$ Angka persentase (ketuntasan belajar)

$f=$ Frekuensi yang sedang dicari persennya (jumlah peserta didik yang berada $\geq$ KKM)

$N=$ Number of case (jumlah frekuensi/banyaknya individu.

\section{Hasil}


Setelah diadakan penelitian perbaikan pembelajaran pada mata pelajaran matematika materi bangun ruang melalui penerapan Pendekatan Matematika Realistik Indonesia (PMRI) pada peserta didik kelas V SDN No. 35 Inpres Panggalo, Kecamatan Banggae, Kabupaten Majene, yang dilaksanakan pada bulan April melalui dua siklus perbaikan, maka dapat disimpulkan tingkat motivasi dan hasil belajar peserta didik.

Data jumlah peserta didik yang termotivasi dan tidak termotivasi serta hasil belajar peserta didik, diketahui melalui pengamatan observasi dan pemberian tes tertulis pada akhir siklus.

\section{Hasil tes evaluasi siklus I}

Adapun skor perolehan hasil evaluasi matematika siklus I disajikan sebagai berikut :

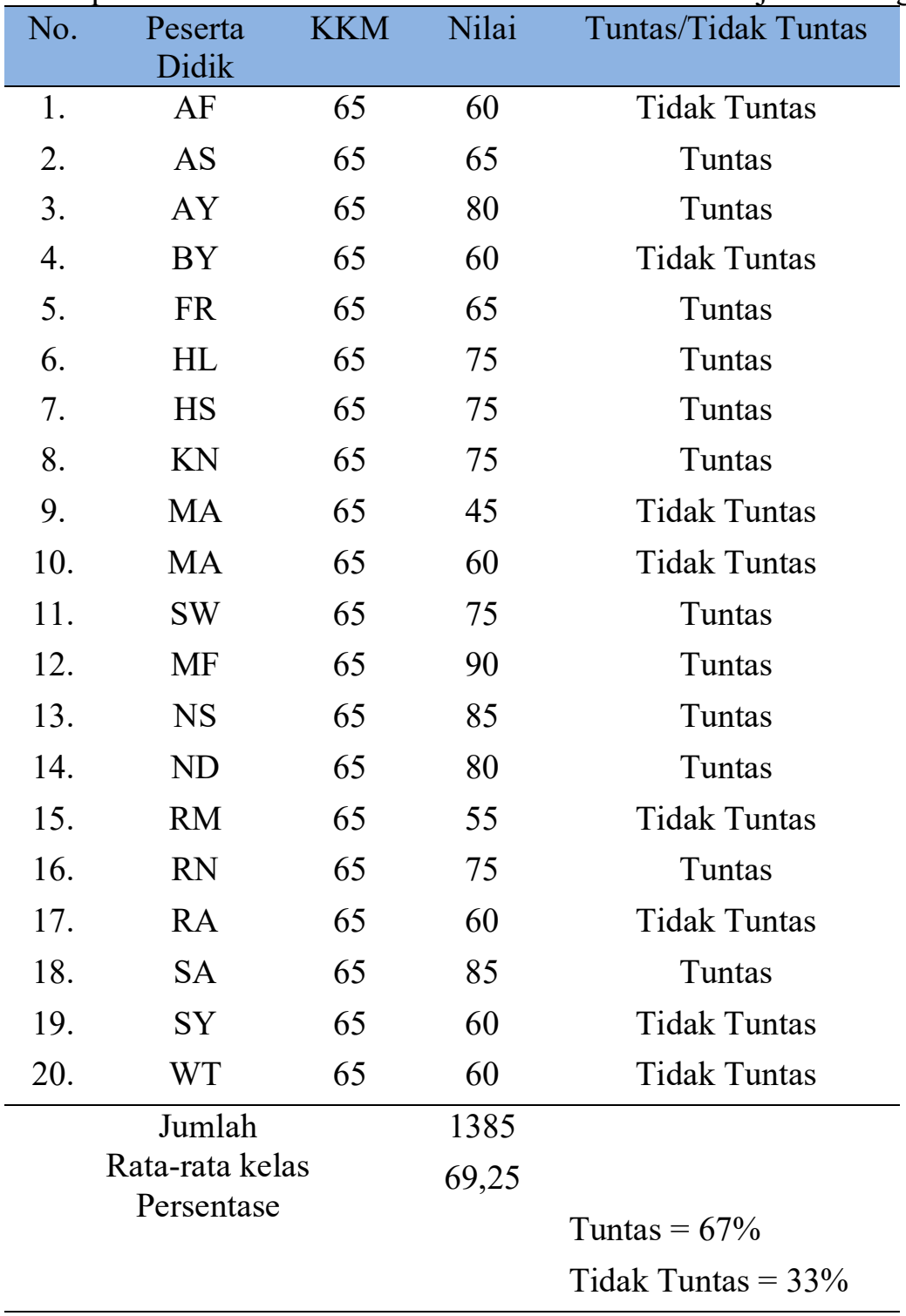

Tabel 4.1 Hasil belajar matematika siklus I

Pada tabel 4.1 tampak bahwa nilai rata-rata kelas hasil belajar peserta didik mata pelajaran matematika pada materi bangun ruang kubus adalah sebesar 69,25 dan nilai terendah adalah 
sebesar 50 dengan jumlah persentase peserta didik yang tuntas belajar adalah sebesar $67 \%$, sedangkan persentase peserta didik yang tidak tuntas belajar adalah sebesar 33\%.

\begin{tabular}{lllll} 
No. & Interval nilai & Kategori & Frekuensi & Persentase \\
\hline 1. & $0-64$ & Kurang & 8 & $33 \%$ \\
2. & $65-75$ & Cukup & 7 & $36 \%$ \\
3. & $76-87$ & Baik & 4 & $24 \%$ \\
4. & $88-100$ & Sangat Baik & 1 & $7 \%$ \\
\hline \multicolumn{2}{r}{ Jumlah } & & 20 & $100 \%$ \\
\hline
\end{tabular}

Tabel 4.2 Interval frekuensi penguasaan matematika kelas V siklus I

Pada tabel 4.2 menunjukkan bahwa persentase skor kemampuan pemecahan masalah peserta didik pada materi bangun ruang kubus setelah penerapan pendekatan Pendidikan Matematika Realistik Indonesia (PMRI) pada siklus I yaitu jumlah peserta didik yang memperoleh nilai berkategori kurang adalah 8 orang dengan persentase $33 \%$, nilai berkategori cukup adalah 7 orang dengan persentase sebesar $36 \%$, nilai berkategori baik adalah 4 orang dengan persentase sebesar $24 \%$, dan 1 orang peserta didik berkategori sangat baik dengan persentase sebesar 7\%. Di samping itu, sesuai dengan rata-rata skor kemampuan menyelesaikan soal cerita tentang bangun ruang kubus peserta didik sebesar 69,25. Jika dikompersi ke dalam tabel, ternyata berada dalam kategori kurang. Oleh karena itu perbaikan pembelajaran perlu dilanjutkan pada siklus berikutnya yaitu siklus II.

\section{Hasil tes evaluasi siklus II}

Adapaun skor perolehan hasil evaluasi matematika siklus II disajikan sebagai berikut :

\begin{tabular}{lllll} 
No. & $\begin{array}{l}\text { Peserta } \\
\text { Didik }\end{array}$ & KKM & Nilai & Tuntas/Tidak Tuntas \\
\hline 1. & AF & 65 & 80 & Tuntas \\
2. & AS & 65 & 70 & Tuntas \\
3. & AY & 65 & 90 & Tuntas \\
4. & BY & 65 & 75 & Tuntas \\
5. & FR & 65 & 70 & Tuntas \\
6. & HL & 65 & 80 & Tuntas \\
7. & HS & 65 & 85 & Tuntas \\
8. & KN & 65 & 80 & Tuntas \\
9. & MA & 65 & 60 & Tidak Tuntas \\
10. & MA & 65 & 60 & Tidak Tuntas \\
11. & SW & 65 & 85 & Tuntas \\
12. & MF & 65 & 100 & Tuntas \\
13. & NS & 65 & 90 & Tuntas \\
14. & ND & 65 & 85 & Tuntas \\
15. & RM & 65 & 60 & Tidak Tuntas \\
16. & RN & 65 & 85 & Tuntas \\
17. & RA & 65 & 65 & Tuntas \\
18. & SA & 65 & 95 & Tuntas \\
19. & SY & 65 & 70 & Tuntas \\
20. & WT & 65 & 75 & Tuntas \\
\hline \multicolumn{5}{r}{ Jumlah } \\
\hline
\end{tabular}




\begin{tabular}{cc}
\hline $\begin{array}{c}\text { Rata-rata kelas } \\
\text { Persentase }\end{array}$ & 78 \\
& $\begin{array}{l}\text { Tuntas }=88 \% \\
\text { Tidak Tuntas }=12 \%\end{array}$ \\
\hline
\end{tabular}

Tabel 4.3 Hasil belajar matematika siklus II

Pada tabel 4.2 tampak bahwa nilai rata-rata kelas hasil belajar peserta didik mata pelajaran matematika pada materi bangun ruang kubus adalah 78 dan nilai terendah adalah 60 dengan jumlah persentase peserta didik yang tuntas belajar adalah $88 \%$, sedangkan persentase peserta didik yang tidak tuntas belajar adalah $12 \%$.

\begin{tabular}{|c|c|c|c|c|}
\hline No. & Interval nilai & Kategori & Frekuensi & Persentase \\
\hline 1. & $0-64$ & Kurang & 3 & $12 \%$ \\
\hline 2. & $65-75$ & Cukup & 6 & $27 \%$ \\
\hline 3. & $76-87$ & Baik & 7 & $37 \%$ \\
\hline 4. & $88-100$ & Sangat Baik & 4 & $24 \%$ \\
\hline \multicolumn{3}{|c|}{ Jumlah } & 20 & $100 \%$ \\
\hline
\end{tabular}

Tabel 4.4 Interval frekuensi penguasaan matematika kelas V siklus II

Pada tabel 4.4 menunjukkan bahwa persentase skor kemampuan pemecahan masalah peserta didik pada materi bangun ruang balok setelah penerapan pendekatan Pendidikan Matematika Realistik Indonesia (PMRI) pada siklus II yaitu terdapat 3 peserta didik berkategori kurang dengan persentase $12 \%$. Hal tersebut menunjukkan adanya penurunan peserta didik yang berkategori kurang apabila dibandingkan dengan siklus I dengan selisih yaitu $21 \%$. Kemudian terdapat 6 peserta didik berkategori cukup dengan persentase 27\%. Hal tersebut menunjukkan perbedaan frekuensi dengan siklus I dimana jumlah peserta didik yang berkategori cukup lebih unggul 9\% dibandingkan dengan siklus II. Akan tetapi, perbedaan yang signifikan terdapat pada peserta didik yang memperoleh hasil belajar dengan kategori baik dan sangat baik, yaitu terdapat 7 peserta didik berkategori baik dengan persentase $37 \%$, apabila dibandingkan dengan siklus I dengan selisih 13\%. Selanjutnya terdapat 4 peserta didik berkategori sangat baik dengan persentase $24 \%$, apabila dibandingkan dengan siklus I dengan selisih $17 \%$.

Dengan demikian, berdasarkan hasil observasi maka dapat dikemukakan bahwa perbaikan pembelajaran tidak perlu lagi dilanjutkan ke siklus berikutnya, karena hasil belajar yang diinginkan telah mencapai target pencapaian tujuan pembelajaran serta ketuntasan belajar di kelas yaitu 88\% sebagaimana yang terdapat dalam kurikulum 1994.

Pembahasan Hasil Penelitian Perbaikan Pembelajaran

1. Siklus I

Pelaksanaan siklus I mata pelajaran matematika materi bangun ruang kubus pada peserta didik kelas V SDN No. 35 Inpres Panggalo, Kecamatan Banggae, Kabupaten Majene, siklus I diawali dengan guru atau peneliti melakukan apersepsi yaitu menanyakan "Siapa di antara kalian yang senang bermain ular tangga? Siapa pula di antara kalian yang pandai memainkan rubik warna?". Selanjutnya guru memperlihatkan model dan alat peraga berupa kardus berbentuk kubus sambil bertanya jawab tentang media yang telah diperlihatkan. Hal tersebut dilakukan untuk menggali pengatahuan awal peserta didik mengenai bangun ruang kubus yang akan dibahas yaitu mengenal benda-benda yang termasuk bangun ruang sederhana (kubus), menggunakan model dan alat peraga bangun ruang kubus untuk menentukan jumlah sisi, titik 
sudut dan rusuk, serta menggunakan kubus satuan untuk menghitung volume berbagai bangun ruang sederhana.

Kemudian guru menyampaikan tujuan yang akan dicapai dari kegiatan pembelajaran. Selanjutnya guru membagi peserta didik dalam beberapa kelompok diskusi dan membagikan Lembar Kerja Siswa (LKS) yang berisi permasalahan yang digunakan untuk mengidentifikasi tentang jumlah sisi, titik sudut, rusuk dan volume kubus menggunakan kubus satuan dengan cara berdiskusi dengan benar dan sekaligus memberikan motivasi kepada peserta didik. Disaat diskusi berlangsung, sesekali guru berkeliling kelas untuk membantu kelompok-kelompok yang mengalami kesulitan dalam menyelesaikan berbagai permasalahan yang diajukan dalam LKS. Pada akhir siklus I, peneliti mengadakan evaluasi dengan menggunakan tes tertulis untuk mengetahui tingkat motivasi dan keberhasilan peserta didik dalam proses pembelajaran.

Berdasarkan hasil observasi siklus I, maka dapat diketahui bahwa terdapat sejumlah peserta didik yang tidak termotivasi. Demikian juga dengan hasil evaluasi menunjukkan masih terdapat banyak peserta didik yang mendapat nilai di bawah KKM. Pada siklus I, nilai rata-rata kelas yaitu 69,25 dan persentase ketuntasan belajar yaitu 67\%. Hal tersebut berarti bahwa hasil belajar yang diinginkan hanya mengalami peningkatan beberapa persen saja dari target pencapaian yaitu 65 .

Berdasarkan hasil pengamatan atau observasi yang peneliti telah lakukan, terdapat beberapa hal yang menjadi penyebab hasil belajar yang kurang maksimal, antara lain:

1. Pembagian kelompok diskusi yang kurang memperhatikan pemerataan penyebaran antara peserta didik yang tingkat prestasinya baik dan yang tergolong rendah di kelas. Dalam hal ini terdapat kelompok yang dimana anggotanya terdiri dari peserta didik yang memiliki prestasi yang baik di kelas dan sebaliknya terdapat pula kelompok yang anggotanya terdiri dari peserta didik, dimana tingkat penguasaan materi dalam proses pembelajaran masih tergolong rendah.

2. Kurangnya kerja sama di antara peserta didik dalam menyelesaikan permasalahan yang perlu diidentifikasi dalam LKS, sehingga dalam hal ini penyelesaian LKS masih didominasi oleh peserta didik yang memiliki prestasi yang baik di kelas.

3. Guru kurang teliti memperhatikan keseriusan peserta didik dalam mengamati media pembelajaran yang sedang dijelaskan.

4. Pada saat berlangsungnya diskusi kelompok, terdapat peserta didik yang terlihat kurang aktif dan menunjukkan sikap egoisme dengan saling melimpahkan tanggung jawab kepada teman kelompoknya.

5. Pada saat proses pembelajaran berlangsung dimana guru sedang menjelaskan dan fokus pada materi yang diajarkan, terdapat peserta didik yang kurang menaruh perhatian dan terdapat pula peserta didik yang ribut bahkan hampir menimbulkan kegaduhan di kelas.

Berdasarkan beberapa hal yang menjadi penyebab hasil belajar peserta didik kurang maksimal seperti yang telah dijelaskan, maka diperlukan adanya sejumlah perbaikan agar dapat meningkatkan motivasi dan hasil belajar peserta didik, yaitu pada siklus berikutnya (Siklus II).

\section{Siklus II}

Pada pelaksanaan siklus II, tindakan pembelajaran mata pelajaran matematika pada materi bangun ruang balok, guru atau peneliti mengawali pembelajaran dengan melakukan apersepsi 
yaitu menanyakan "Siapa yang pernah disuruh ibunya ke minimarket?, kira-kira barang dagangan apa saja yang biasa dijual di minimarket?" kemudian guru memperlihatkan model dan alat peraga berupa kardus berbentuk balok sambil bertanya jawab tentang media yang telah diperlihatkan. Hal tersebut dilakukan untuk menggali pengetahuan awal peserta didik mengenai bangun ruang balok yang akan dibahas yaitu mengenal benda-benda yang termasuk bangun ruang sederhana (balok), menggunakan model dan alat peraga bangun ruang balok untuk menentukan jumlah sisi, titik sudut dan rusuk, serta menggunakan kubus satuan untuk menghitung volume bangun ruang balok.

Kemudian guru menyampaikan tujuan yang akan dicapai dari kegiatan pembelajaran disertai dengan memberikan motivasi dan mengamati keseriusan peserta didik dalam mengikuti pembelajaran yang sedang berlangsung. Setelah itu guru membagi ke dalam empat kelompok kecil beranggotakan lima peserta didik, dimana pembagian setiap kelompok dengan memperhatikan pemerataan penyebaran antara peserta didik yang tingkat prestasinya baik dan tergolong rendah di kelas. Sebelum dimulainya diskusi kelompok, guru terlebih dahulu menjelaskan kepada peserta didik akan pentingnya kerja sama, tidak saling melimpahkan tanggung jawab dan tidak menunjukkan sikap egoisme antara anggota kelompok, serta hal terpenting yang perlu menjadi perhatian peserta didik adalah tidak melakukan berbagai perilaku penyimpangan yang dapat berakibat pada timbulnya kegaduhan terutama pada saat berlangsungnya kegiatan pembelajaran di kelas.

Selanjutnya guru mengajukan beberapa pertanyaan kepada setiap anggota kelompok termasuk penggunaan media dan alat peraga bangun ruang balok dan kubus. Kemudian guru membagikan Lembar Kerja Siswa (LKS) kepada setiap anggota kelompok untuk menyelesaikan berbagai permasalahan yang diajukan sesuai dengan rentang waktu yang telah ditentukan. Setelah selesai mengerjakan dan mengetahui jawabannya, guru meminta peserta didik mempresentasikan hasil kerja kelompoknya di depan kelas secara bergantian.

Pada kegiatan akhir pembelajaran, guru memberikan tes evaluasi secara tertulis yang dikerjakan secara mandiri oleh setiap peserta didik. Setelah itu dengan bimbingan guru, peserta didik menyimpulkan materi pelajaran yang telah diajarakan.

Berdasarkan hasil pengamatan atau observasi dan hasil belajar yang diperoleh pada siklus II, menunjukkan bahwa beberapa kekurangan dan dan kelemahan yang telah dipaparkan pada siklus I merupakan faktor-faktor utama penyebab ketidakberhasilan antara peserta didik dan guru dalam proses pembelajaran. Sehingga telah dilakukan perbaikan-perbaikan secara menyeluruh yang dilaksanakan pada siklus II. Sebagaimana dengan siklus I, setelah semua data observasi motivasi dan hasil belajar dikumpulkan dan dianalisis secara cermat, maka dapat diperoleh peningkatan hasil belajar peserta didik. Hal tersebut terbukti dari hasil evaluasi yang diberikan pada akhir siklus II diperoleh nilai rata-rata kelas yaitu 78, dengan persentase ketuntasan belajar pada siklus I yaitu $67 \%$ menjadi $88 \%$ pada siklus ke II. Sehingga dengan demikian, target pencapaian yang diharapkan telah memenuhi persyaratan ketuntasan belajar di kelas.

Dari uraian pembahasan siklus I dan siklus II, mendiskripsikan bahwa guru memilki peranan penting dalam mengatasi kesulitan belajar peserta didik. Guru perlu mengupayakan adanya situasi, kondisi, strategi, materi maupun teknik bantuan belajar matematika yang menyenangkan. Pembelajaran yang menyenangkan menuntut adanya kebebasan pembelajaran, 
sehingga peserta didik dapat mengungkapakan makna sebagai hasil dan interprestasinya terhadap segala sesuatu di dunia nyata. Sedangkan pembelajaran bermakna merupakan suatu proses dikaitkannya informasi baru pada konsep-konsep relavan yang terdapat dalam struktur kognitif seseorang. Selain itu, peran utama guru tidak hanya sebagai pengajar dan mentransfer ilmu pengetahuan yang dimiliki, melainkan berperan sebagai fasilitatar dan motivator bagi seluruh peserta didik.

\section{Kesimpulan}

Berdasarkan hasil penelitian dan pembahasan yang disajikan dapat diperoleh kesimpulan bahwa penerapan Pendidikan Matematika Realistik Indonesia (PMRI) dapat meningkatkan proses pembelajaran dan hasil belajar matematika peserta didik kelas V SDN No. 35 Inpres Panggalo, Kecamatan Banggae, Kabupaten Majene. Peningkatan proses pembelajaran dapat dilihat dari hasil observasi dan hasil belajar peserta didik. Peningkatan hasil belajar dapat dilihat dari nilai yang diperoleh. Pada siklus I rata-rata nilai yang diperoleh adalah 69,25 meningkat pada siklus II menjadi 78. Jumlah peserta didik yang mencapai ketuntasan pada siklus I sebanyak 12 peserta didik atau sebesar $67 \%$ dan pada siklus II meningkat menjadi 17 peserta didik atau sebesar $88 \%$. Dengan melihat persentase dari siklus I ke siklus II, menunjukkan adanya peningkatan hasil belajar peserta didik sebesar $21 \%$.

\section{Referensi}

\section{Sumber Buku}

D. pribadi, Benny. (2009). Model Desain Sistem Pembelajaran. Jakarta: Dian Rakyat.

Hawa, A. (2007). Pengembangan Pembelajaran Matematika Sekolah Dasar. Jakarta: Dirjen Dikti.

Purwanto, M. Ngalim. (2002). Prinsip-Pririnsip dan Teknik Evaluasi Pengajaran. Bandung: PT. Remaja Rosdakarya.

Sanjaya, Wina. (2011). Standar Pembelajaran Berorientasi Standar Proses Pendidikan. Bandung: PT. Remaja Rosdakarya.

Suardi, Muhammad. (2015). Belajar dan Pembelajaran. Yogyakarta: Deepublish

Sugihartono, dkk. (2007). Psikologi Pendidikan. Yogyakarta: UNY Press.

Slameto. (2010). Belajar dan Faktor-faktor yang Mempengaruhinya. Jakarta: Rineka Cipta.

Suharta, I Gusti Putu. (2001). Penerapan Pembelajaran Matematika Realistik Untuk Mengembangkan Pengertian Siswa. Yogyakarta: Universitas Sanata Darma.

Suherman, Erman, dkk. (2003). Strategi Pembelajaran Matematika Kontemporer. Bandung: PT. Remaja Rosda Karya.

Supinah, dkk. (2008). Pembelajaran Matematika SD dengan Pendekatan Kontekstual dalam Melaksanakan KTSP”. Yogyakarta: P4TKM. 
Trianto. (2007). Model-model Pembelajaran Inovatif Berorientasi Konstruktivistik. Surabaya: Prestasi Pusaka.

Wahyudi dan Kriswandi. (2007). Pengembangan Pembelajaran Matematika. Salatiga: Widya Sari Press.

Widayanti, Esti Yuli, dkk. (2009). Pembelajaran Matematika MI. Surabaya: LAPIS-PGMI.

Yusuf, munawir. (1997). Mengenal Siswa Berkesulitan Belajar. Jakarta: Depdikbud.

\section{Sumber Internet}

http://www.munirkantkj.blogspot.com (Diunduh 10 April 2019). 